\title{
Historical Forage Productivity and Cost of Capital for Cow-Calf Production in California
}

\author{
Philip Brownsey, ${ }^{1}$ Jose L. Oviedo, ${ }^{2}$ Lynn Huntsinger, ${ }^{3}$ and Barbara Allen-Diaz ${ }^{3,4}$ \\ Authors are ${ }^{1}$ Range Program Manager, US Forest Service, Redding, CA 96002, USA; ${ }^{2}$ Associate Research Professor, Institute of Public Goods and Policies \\ (IPP), Spanish National Research Council (CSIC), 28037 Madrid, Spain; ${ }^{3}$ Professor, Department of Environmental Science, Policy and Management, \\ University of California, Berkeley, Berkeley, CA 94720, USA; and ${ }^{4}$ Vice President, Division of Agriculture and Natural Resources, University of \\ California, Oakland, CA 94607, USA.
}

\begin{abstract}
Exposure of livestock grazing to forage productivity variation and to market fluctuations affects the risk of investment and returns from cow-calf operations, but little work has been done to empirically compare these returns to the returns that would be demanded by financial markets from assets with similar risk and return characteristics. This study uses historical forage production data from three rangeland locations in California, and cattle and hay prices, to simulate financial statements for three hypothetical cow-calf producers in the period 1988-2007. Return on investment from year to year incorporates the variability and risk associated with dependence on natural forage production. Performance is then compared to the actual performance of a diversified portfolio of assets using the Capital Asset Pricing Model, from which the theoretical cost of capital for these hypothetical grazing enterprises is derived. Much like other agricultural enterprises, cow-calf production in California has low market risk and a low theoretical cost of capital. This theoretical cost of capital is still greater than the historical return from livestock production (excluding land appreciation) in the western United States, adding further backing to the point often made in the literature that ranchers who engage in cow-calf production are receiving benefits beyond the commercial returns from livestock production alone.
\end{abstract}

Key Words: bioeconomic model, capital asset pricing, financial risk, rangeland economics

\section{INTRODUCTION}

Grazing livestock on natural forage is the most traditional form of western livestock production and is often pointed to as valuable means of making use of nonarable lands for food production (Starrs 1998), yet the more dependent a rancher is on native range, the more subject the operation is to the natural variation in forage production that results from weather patterns. Such variation can be quite high and unpredictable, leading to the characterization of rangeland at the arid end of the spectrum as dominated by nonequilibrium dynamics (Vetter 2005). Exposure to this kind of variation could have an impact on the risk of investment and the returns from cow-calf operations, in addition to the risk associated with market variability related to either cattle prices or to hay prices as a supplementary source of food in years of low forage productivity.

Although there is an extensive literature about the low returns on investment for western ranching, little work has been done to empirically compare the livestock production component of these returns, especially as related to forage

\footnotetext{
Research was funded by the Russell Rustici Endowed Chair at University of California, Berkeley, by the Forest and Rangeland Assessment Program of the California Dept of Forestry and Fire Protection, and by the Intramural Grant 2009101130 (Avances en técnicas econométricas aplicadas a la valoración ambiental y a modelos de cambio de uso del suelo) of the Spanish National Research Council.

Philip Brownsey and Jose L. Oviedo share first-authorship of the article.

Correspondence: Jose L. Oviedo, Institute of Public Goods and Policies (IPP), Spanish National Research Council (CSIC), Albasanz 26-28, 3D26, 28037 Madrid, Spain. Email: jose.oviedo@cchs.csic.es
}

Manuscript received 29 March 2011; manuscript accepted 2 December 2012

(c) 2013 The Society for Range Management production and cattle and hay prices, to the returns that would be demanded by financial markets from assets and investments with similar risk and return characteristics. For policy makers, managers, and ranchers, knowing the financial performance and risk-return characteristics of cow-calf operations as compared to alternative financial assets is crucial to understanding the long-term financial viability of ranch enterprises, especially if sustaining working landscapes is a policy goal. Rangeland management sustainability is more likely when the rancher is able to conduct a profitable business, and this has a direct impact on the conservation of rangeland working landscapes given the threat of fragmentation and land use change. In California, land conversion drives important ecological and socioeconomic changes in rangeland landscapes. The Natural Resources Inventory of the US Department of Agriculture (USDA) estimated that between 1982 and 2003, rangeland in California decreased 6\% (USDA 2000, 2003). The Fire and Resource Assessment Program (2003) estimates that about 12000 ha of hardwood woodland and grasslands will be converted to urban uses every year in California up to 2040.

The cost of capital (Sharpe 1964; Lintner 1965; Merton 1973 ) is the rate of return that a firm would have been able to earn had it invested in some other business at the same risk level, and is used as the benchmark against which to measure the value of future benefits of an enterprise to determine its viability. Textbooks, articles, and bulletins are published to assist range managers and ranchers in decision-making and to estimate the cost of capital of grazing operation investments. However, costs for grazing operations are dependent on forage production, and the site-specific information about forage production over many years that would help to estimate the 
likely variations in future production is often difficult to come by.

California's Mediterranean rangelands include annual grasslands with and without an oak woodland overstory. These grasslands are productive but have nonequilibrium rangeland dynamics, with annual forage production varying unpredictably by a factor of three or more (George et al. 2001). In this study, we use historical forage production data from three such locations to simulate financial statements for three hypothetical cow-calf producers for a 20 -yr period. The variability in return on investment from year to year is measured incorporating the variability and risk associated with dependence on natural forage production. We also use the variability of cattle and hay (as substitutes of forage in years of low production) prices with dependence on market variability to simulate these financial statements. This performance is then compared to the actual performance of a diversified portfolio of investment assets based on the Capital Asset Pricing Model (CAPM), from which the theoretical cost of capital for these hypothetical cow-calf enterprises is derived.

\section{METHODS AND MATERIALS}

\section{Using the CAPM}

To evaluate the cost of capital of investment projects, the theory of asset pricing has been extensively applied to investment portfolio management (Sharpe 1964; Lintner 1965). The CAPM is not new and has typically been used to estimate the efficient return on an asset given its covariance with a market return (the return on a completely diversified portfolio of all available assets). In a market equilibrium, the CAPM expresses the relationship between an asset's expected return and its systematic risk as the sum of a risk-free rate and a risk premium (Barry 1980).

Dusak (1973), Barry (1980), and Arthur et al. (1988) applied the CAPM to assess the risk-return characteristics of agricultural assets in a portfolio context, finding that agricultural assets carry an insignificant systematic risk and low cost of capital. While these studies provide an indication of the performance of agricultural assets, they do not directly look at the returns from grazing at the enterprise level, and do not estimate its theoretical cost of capital according to the CAPM. Applying the CAPM to cow-calf livestock production can offer insights on its systematic risk and on its risk-return characteristics that can be compared to risk-free asset returns in the market.

Our CAPM application provides estimates of risk and theoretical cost of capital for grazing-based cow-calf production based on hypothetical cow-calf operations on the three annual grassland and oak woodland sites for which we have historical data. We use $20 \mathrm{yr}$ of data from financial statements that are built upon actual forage production records from these three sites and the concurrent California hay and cattle prices. This is the first application of the CAPM to livestock grazing and the first estimation of the associated systematic risk. While previous CAPM applications to agriculture (Barry 1980; Arthur et al. 1988) employ farm real estate and price indexes to compute rate of returns from agricultural assets, our study relies on financial statements built upon actual data from three ranching sites with their particular exposure to variation in forage production, and to cattle and supplementary feed prices. Although the CAPM methodology dates from the 1960s, it is still used to evaluate the risk-return characteristics of the agricultural enterprise (as, for example, in American Agricultural Economics Association [AAEA] 2000, p. 2-37) and complement other studies that have analyzed livestock grazing returns and investments using alternative methods (Torell et al. 2001; Campos et al. 2009).

We evaluate grazing-based cow-calf production as one component of the socio-ecological system termed "ranching," and cow-calf returns are isolated here from the many other market and nonmarket returns that ranchers obtain (Smith and Martin 1972; Pope 1985, 1987; Liffmann et al. 2000; Torell et al. 2005; Campos et al. 2009; Huntsinger et al. 2010). In particular this analysis is performed without considering the appreciation of land value that is often part of family or corporate ranching investment decisions when the land is owned by the livestock producer, or other market (e.g., income from hunting) or nonmarket (e.g., lifestyle) benefits that ranchers give value to when considering alternative investments (Campos et al. 2009). Instead, this assessment is for a rangeland enterprise that can take place on owned or leased land with owned or contracted cattle: all these forms are common on rangelands today.

\section{Model Description}

The CAPM estimates the risk of a particular asset by measuring the variability in its return above a risk-free rate relative to a diversified market portfolio (Sharpe 1964; Merton 1973; Barry 1980; Arthur et al. 1988). The risk associated with this part of the returns from an asset is known as systematic risk. The risk associated with returns that vary independently of the returns from the other assets in the portfolio, such as the gain or loss of an individual contract, an accident that results in losses to the business, or particularly good or poor management decisions, is known as unsystematic risk. Unsystematic risk is diversifiable by holding a broad range of assets. Systematic risk is not diversifiable, and investors demand a higher cost of capital for assets with higher systematic risk.

Following the CAPM, it is expected that the higher the systematic risk of an asset, the higher the expected returns for that asset (Arthur et al. 1988). The CAPM can be expressed in the general form:

$$
\mathrm{E}\left[R_{i}\right]=R_{F}+\beta_{i}\left(\mathrm{E}\left[R_{M}\right]-R_{F}\right),
$$

where $E\left[R_{i}\right]$ is the expected return on the asset of interest, $R_{F}$ is the risk-free rate of return, $E\left[R_{M}\right]$ is the expected market return, and $\beta_{i}$ is the estimated systematic risk. Subtracting the risk-free rate of return from either side of equation [1] results in an equation (Arthur et al. 1988) that can be estimated using Ordinary Least Squares:

$$
r_{t}=\alpha+\beta r_{m t}+\varepsilon_{t}
$$

where $r_{t}$ is the return on the asset of interest above the risk-free rate, $\alpha$ is an intercept, $\beta$ is the systematic risk of the asset of interest, $r_{m t}$ is the return on a diversified market portfolio of assets above the risk-free rate, and $\varepsilon_{t}$ is unexplained variation in the model. 
If $\alpha$ is equal to zero, the CAPM holds and the asset of interest is priced efficiently according to the market risk. An $\alpha$ above zero means that the enterprise is obtaining extraordinary returns above the returns implied by its systematic risk and thus the asset is priced too low. On the contrary, an $\alpha$ below zero means that there are low returns to the enterprise and thus the asset is priced too high (Barry 1980; Arthur et al. 1988).

As $\beta$ reflects the systematic risk of the asset, its interpretation provides information about the higher or lower returns that the asset of interest generates according to the CAPM and a diversified market portfolio. If $\beta$ is equal to zero, the asset has no correlation with the diversified market portfolio and would be equal to a "risk-free" asset. If $\beta$ is less than zero, the asset has less systematic risk than a "risk-free" asset, and if $\beta$ is more than one, the asset has more systematic risk than a diversified market portfolio.

According to the CAPM, the expected return of the asset of interest if the market is efficient can be estimated using equation [1], substituting $R_{F}$ by the average return of a riskfree asset for the analyzed period, $\mathrm{E}\left[R_{M}\right]-R_{F}$ by the premium return of a diversified market portfolio over the risk free asset, and $\beta$ by the value estimated for this parameter in equation [2].

In our application, the CAPM explains cow-calf returns based on their correlation with risk variability to find out the premium (or the opposite) returns of cow-calf production in a 20 -yr period and what the theoretical cost of capital is of this investment. Variability in our analysis is captured with data variation for three key factors in cow-calf production: forage production, calf prices, and hay prices. Costs that are relatively stable over the analyzed time horizon are expected to have little influence in the $\beta$ estimations (see Results sections).

\section{Building Financial Statements}

Cow-calf hypothetical operations are simulated with a herd of 300 breeding cows, as this is approximately the minimum size of a ranch herd commonly thought to be necessary to sustain one household (Forero et al. 2004).

Based on cost estimates for a 300 head cow-calf ranch operation in California's Sacramento Valley in 2004 (Forero et al. 2004), we assume a $90 \%$ calf-crop, $85 \%$ weaning success, and a $5 \%$ loss of weanlings. Herd replacement accounts for 24 cull cows, six dead cows ( $2 \%$ cow mortality), and two cull bulls. There are also eight culled replacements that are sold. Thus, revenue is calculated considering the sale of 205 calves in June (87 heifer calves and 118 steer calves once replacements are removed), 24 cull cows and two cull bulls in March, and eight yearling heifers in September. Steer calves are sold at 273 $\mathrm{kg}$, heifer calves at $260 \mathrm{~kg}$, cull cows at $523 \mathrm{~kg}$, cull bulls at 795 $\mathrm{kg}$, and yearling heifers at $341 \mathrm{~kg}$. Gross revenue per year is calculated using the market price of each livestock class for the corresponding month each year in California (National Agricultural Statistics Service [NASS] 2007) for livestock sold at the corresponding weights (Appendix 1).

Estimated forage costs are based on forage production data from three sites in California. These sites include the University of California's Sierra Foothill Research and Extension Center (near Brown's Valley, California, in Yuba County: lat $39^{\circ} 15^{\prime} 04.07^{\prime \prime} \mathrm{N}$, long $\left.121^{\circ} 18^{\prime} 47.27^{\prime \prime} \mathrm{W}\right)$, Hopland Research and Extension Center (near Hopland, California, in Mendocino
County: lat $39^{\circ} 00^{\prime} 08.28^{\prime \prime} \mathrm{N}$, long $\left.123^{\circ} 05^{\prime} 03.84^{\prime \prime} \mathrm{W}\right)$, and San Joaquin Experimental Range (near O’Neals, California, in Madera County: lat $37^{\circ} 05^{\prime} 44.88^{\prime \prime} \mathrm{N}$, long $\left.119^{\circ} 43^{\prime} 45.12^{\prime \prime} \mathrm{W}\right)$. We refer to the three sites as the Sierra Foothill site, the Hopland site, and the San Joaquin site, respectively. Each is characterized by a Mediterranean climate with hot, dry summers; cool, wet winters; and high variability in precipitation from year to year. Forage production has been monitored on a yearly basis since 1953 at the Sierra Foothill site, since 1980 at the Hopland site, and since 1936 at the San Joaquin site. These forage production datasets are described in George et al. (2001). Personal communications (D. Flavell, August 2007; C. Vaughn, September 2007; N. McDougald, October 2007) with the individuals responsible for collecting and maintaining these datasets at each of these research centers allowed us to update and extend the data beyond what was used in George et al. (2001). For the San Joaquin and the Hopland sites, the analyzed period is 19882007; for the Sierra Foothill site, the analyzed period is 19871989 and 1991-2007 (1990 forage data were missing for this site). Thus, the time period of analysis provides 20 observations for each of the three simulations.

We assume that the livestock producer leases the same number of hectares every year of the analyzed period according to a hypothetical multiyear lease contract, as is typical in California. We set the number of hectares contracted for in our hypothetical multiyear lease according to the average forage production in each site from our datasets. This is done on the assumption that livestock producers have knowledge of the area, including familiarity with forage productivity patterns on local ecological sites, and based on this they negotiate the lease contract. We also assume that the management target is consumption of $50 \%$ of available forage (Holechek et al. 2004, p. 233-236). Thus, for each site, the estimated hectares to be contracted for grazing the $300 \mathrm{cow}$-calf herd through the period of the study is calculated by dividing the total forage requirements for the herd by half of the forage production averaged over the analyzed period for each site.

The market value of this forage is then calculated as the number of hectares leased multiplied by the lease rate per hectare for rangelands in the region of the site for each year (California Chapter, American Society of Farm Managers and Rural Appraisers 2007). This amount is then charged as an annual cost in the ranching financial statement. Additionally, as a grazing restriction we assume that for any year in which forage consumption by the 300 head breeding cow herd exceeds $70 \%$ of available forage, ranchers substitute hay for forage on a 1-for-1 basis, to avoid the long term impacts of having to reduce the herd or overutilize the range. In these years, hay is charged in the financial statement as a cost based on the market price for alfalfa hay in California during the corresponding year (NASS 2007).

We think this is a realistic scenario, though it lacks the flexibility present in other studies. For example, in Torell et al. (2010), a strategy is presented where ranchers can decide their stocking rates from year to year. We do not leave room for renegotiation of lease contracts during the analyzed period, or for moving the herd to other sites. Competition for leases in California is intense and many studies have found that this is one of the main constraints ranchers face (Sulak and Huntsinger 2002). Also, leasing more or less land each year would 
not help to establish the stable relationship between the lessee and the lessor that is generally assumed to foster good management.

Assuming that the rancher does not own the land, and by charging only the market value of the grazing lease as a cost, we avoid including benefits not directly related to cow-calf production, for example those related to real estate. Land is not considered in our investment scenario since it normally implies a wider range of benefits that are not the focus of this paper. We include in the estimated financial statements only the necessary inputs for rangeland cow-calf production (i.e., land rent). Our analysis attempts to avoid attributing financial performance related to real estate or other ranching activities to cow-calf production.

Gas costs are also included in the financial statement, derived from multiplying an average consumption of 15142 liters $\cdot \mathrm{yr}^{-1}$ times the gas price during the corresponding year. "Other costs" are estimated based on Forero et al. (2004) and USDA (2011), and are meant to capture costs of insurance, taxes, maintenance, repairs, freight, marketing, brand inspection, and veterinary expenses. Using costs estimates from Forero et al. (2004), we subtracted from the total costs of $\sim \$ 152000$ the rental costs of grazing land, supplementary feeding, and fuel since these are already included in our financial simulations. This leaves us with $\sim \$ 64000$ at 2004 prices, which is adjusted by the Gross Domestic Product (GDP) Deflator (Bureau of Economic Analysis 2008) to $\sim \$ 70000$ at 2007 prices. This is very similar to an estimate based on costs from the USDA (2011) commodity costs and returns estimations, which is $\sim \$ 75000$ at 2007 prices including gas costs. Based on these estimates, we arrive at $\$ 70000$ in 2007 dollars as the approximate amount of "Other costs" to be charged in the financial statements. This value was adjusted for each year prior to 2007 by the GDP Deflator.

Investment value for the cow-calf operation is assumed to be $\$ 500000\left(\$ 1667 \cdot \mathrm{cow}^{-1}\right)$ in 2007 . This value is also adjusted for each year prior to 2007 by the GDP Deflator. This is meant to roughly estimate the investment in the breeding cow herd including cows, bulls, and replacement, a small infrastructural base, barn, truck, trailer, and any other manufactured assets. These other cost and investment values are assumed to be relatively stable and thus similar for the three ranch sites simulations. Indeed, adjusting them affected the estimate of return $(\alpha)$ in the model, but had little impact on the estimate of systematic risk $(\beta)$, which is the main focus of our analysis.

Return on investment for each year is then calculated by subtracting the total of costs from revenue, and dividing by investment. Appendix 1 presents an example of financial statement calculations for each of the three sites in 2007. We also present the results of a sensitivity analysis for other costs and investment assumptions in Appendix 2.

In this paper, we do not attempt to estimate the actual financial return of cow-calf production from these financial simulations. These simulations allow for estimating the $\beta$ that is used in the CAPM for offering the theoretical cost of capital of the analyzed investment. The returns obtained from our financial statements are approximate, since although we try to assume the most realistic data, they are affected by several assumptions that could differ among study sites and could be dependent on rancher ability and on local market conditions.

\section{Portfolio Investment and Risk-Free Assets}

In order to apply the data from financial statements in the CAPM, a portfolio of market investment is needed to measure the risk variability of cow-calf ranching returns for this portfolio. As an estimate of the risk-free rate of return $\left(R_{F}\right.$ in equation [1]), the average return of the 3-mo T-Bill (Federal Reserve Board of Governors 2007) for the year ending September 30 was used. That is, we calculate the average annualized return on 3-mo (90-d) T-Bills for the year ending September 30 of each year for the period of analysis. To that end, this interest rate is converted back to a 90-d quote based on quarterly compounding over the total days in the year. We divide this by $90 \mathrm{~d}$ and multiplied by the actual days in the month. We take the average interest rate for each month in the fiscal year and compounded it monthly, and then estimate the mean risk-free rate for the entire period. As the estimate of the expected market return $\left(E\left[R_{M}\right]\right.$ in equation [1]), we use the average annual return on the S\&P 500 stock market index (Standard \& Poor's 2007) for the year ending September 30. Average values are calculated for years starting in October and ending in September because this corresponds to the forage production year (with the beginning of fall and winter rains) and the start of fall calving.

\section{RESULTS}

First we test to see if the forage production data are consistent with a normal distribution. Table 1 presents the results of the Shapiro-Wilks normality test for the three site forage datasets, showing that we cannot reject the null hypothesis of the data being consistent with a normal distribution. Figure 1 presents a histogram of the forage production datasets for each site (San Joaquin, Hopland, and Sierra Foothill), along with the normal distribution curve for the corresponding mean and standard deviation.

Ordinary least squares are used to estimate $\beta$ and $\alpha$ in equation [2]. Table 2 shows these regression results for the three simulated cow-calf operations in California for the period 1988-2007 (1987-2007 excluding 1990 for the Sierra Foothill site) and compares them to the results obtained in three previous studies of risk and return for agricultural assets (Dusak 1973; Barry 1980; Arthur et al. 1988).

The estimated $\beta$, or systematic risk, for the three sites falls in the low range of all 41 assets analyzed in previous studies as well as the group of seven assets that are more closely related to the type of cow-calf operation studied here. Like the seven assets shown in Table 2 , the estimated $\beta$ is not statistically significantly different from zero (Table 2 ). This implies that the ranch return does not imply a market risk premium over the risk-free rate in the analyzed period in this study.

According to the estimated risk levels $(\beta)$ in equation [2] (Table 2), and assuming that the market is efficient, we estimate that the expected returns for the three simulated ranches in California are $5.38 \%, 4.43 \%$, and $5.28 \%$ for the San Joaquin, Hopland, and Sierra Foothill sites, respectively (Table 3).

The main differences among the results from the simulated operations derive from the forage productivity and its variability on each site. Table 3 shows the average forage production for the studied period, and the coefficient of 
Table 1. Descriptive statistics and Shapiro-Wilks test (normality test) results for the forage productivity data $\left(\mathrm{kg} \cdot \mathrm{ha}^{-1}\right)$ for the three studied sites $(n=20$ in the three sites).

\begin{tabular}{|c|c|c|c|c|c|c|}
\hline \multirow[b]{2}{*}{ Sites } & \multirow[b]{2}{*}{ Mean $\left(\mathrm{kg} \cdot \mathrm{ha}^{-1}\right)$} & \multirow[b]{2}{*}{ Standard deviation } & \multicolumn{2}{|c|}{ Range } & \multicolumn{2}{|c|}{ Shapiro-Wilks test } \\
\hline & & & Minimum & Maximum & Statistic & $P$ value \\
\hline San Joaquin & 2289.23 & 998.11 & 904.50 & 4449.80 & 0.933 & 0.180 \\
\hline Hopland & 2815.08 & 618.48 & 1961.50 & 3894.00 & 0.929 & 0.146 \\
\hline Sierra Foothills & 3322.20 & 996.06 & 1200.40 & 4943.00 & 0.942 & 0.260 \\
\hline
\end{tabular}

variation of the estimated rate of return and of the forage production for each site. The coefficient of variation is a measure of variability (or dispersion) of year-to-year data around the mean in the analyzed period, and is calculated as the ratio of the standard deviation to mean. Based on this information (Table 3), it seems that what explains a higher expected rate of return based on the CAPM is higher forage productivity variation rather than total forage production.
Hopland, the site with the lowest forage productivity variation, produces the lowest expected rate of return. San Joaquin, where average forage productivity is the lowest but variation is highest, has the highest expected rate of return. Sierra Foothill has the highest total forage production among the three sites, but both its forage production variation and expected rate of return are lower than those of the San Joaquin site. Rate of return variation is positively related to forage production
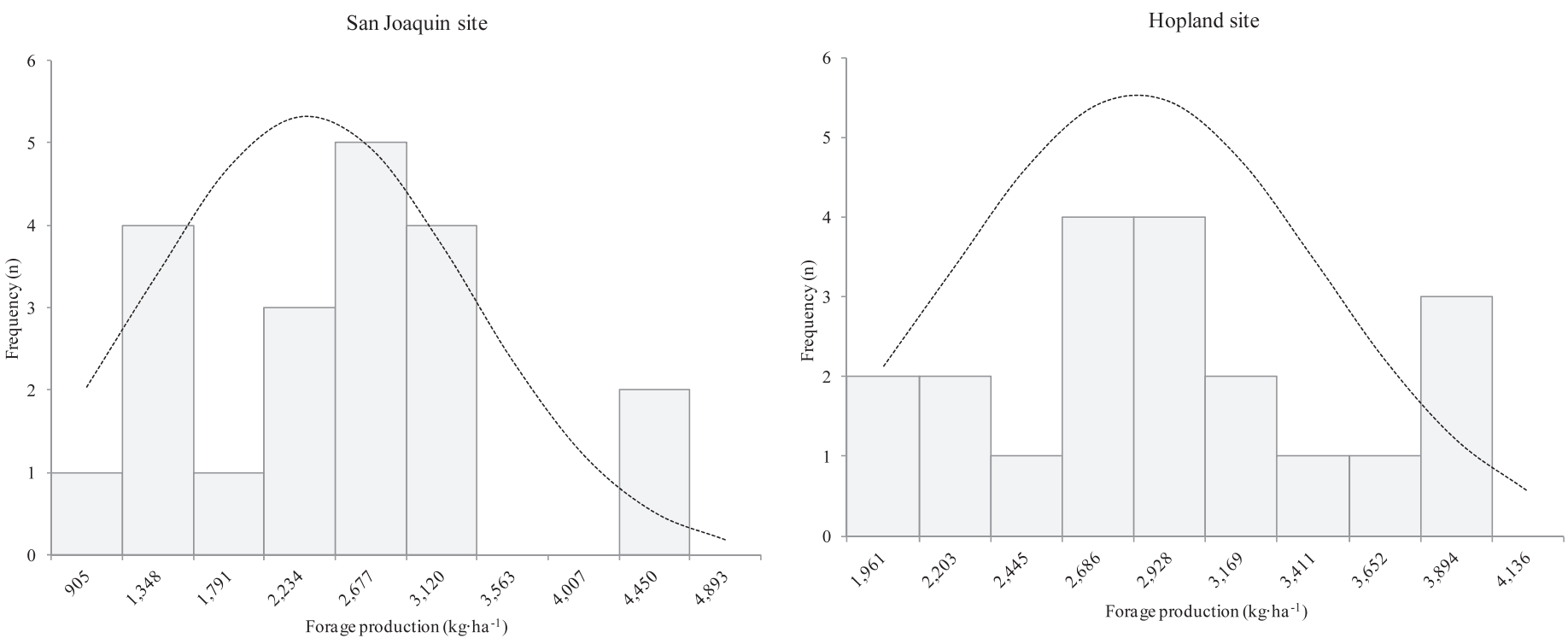

Sierra Foothill site

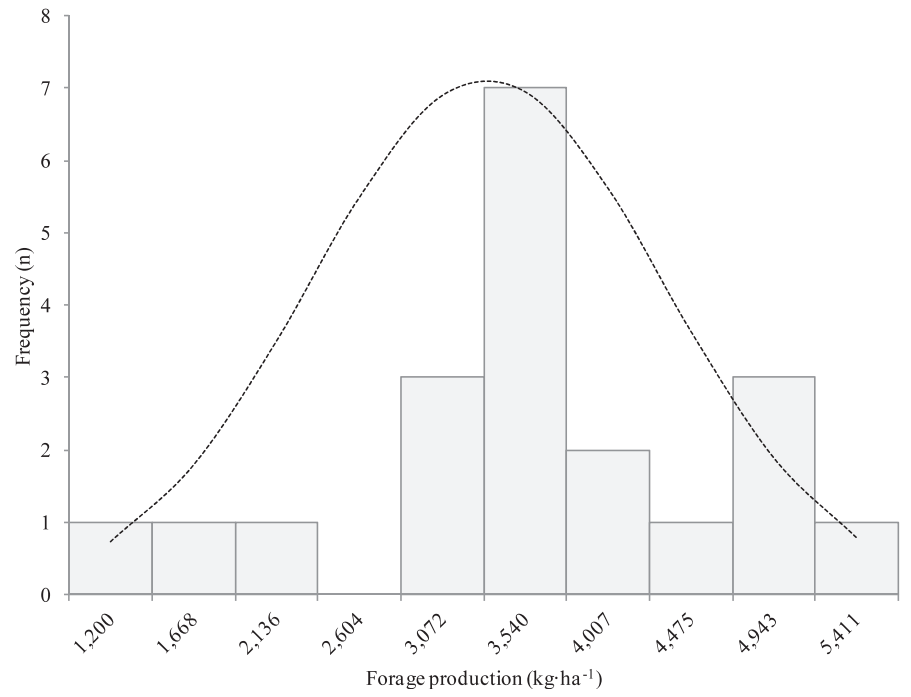

Figure 1. Histogram of the forage production datasets for each site (San Joaquin, Hopland, and Sierra Foothill). The dashed lines illustrate the normal distribution relative to the data. 
Table 2. Regressions results of $\alpha$ and $\beta$ for the Capital Asset Pricing Model for three simulated cow-calf production sites in California with comparison to the results from previous studies analyzing agricultural assets.

\begin{tabular}{|c|c|c|c|c|}
\hline & $\alpha(\mathrm{SE})$ & $\beta$ (SE) & $\mathrm{df}^{4,5}$ & Time period \\
\hline \multicolumn{5}{|l|}{ Sites } \\
\hline Cow-calf, San Joaquin site & $\begin{array}{c}-0.034 \\
(0.022)\end{array}$ & $\begin{array}{c}0.078 \\
(0.119)\end{array}$ & 18 & 1988-2007 \\
\hline Cow-calf, Hopland site & $\begin{array}{c}0.018 \\
(0.013)\end{array}$ & $\begin{array}{r}-0.052 \\
(0.070)\end{array}$ & 18 & 1988-2007 \\
\hline Cow-calf, Sierra Foothill site & $\begin{array}{r}-0.024 \\
(0.020)\end{array}$ & $\begin{array}{c}0.059 \\
(0.099)\end{array}$ & 18 & 1987-2007 (1990 excluded) \\
\hline \multicolumn{5}{|l|}{ Previous studies in agricultural assets } \\
\hline Agricultural real estate, Pacific $^{1}$ & $\begin{array}{l}0.058^{\star * \star} \\
(0.011)\end{array}$ & $\begin{array}{c}0.140 \\
(1.750)\end{array}$ & 26 & $1950-1977$ \\
\hline Agricultural real estate, Mountain ${ }^{1}$ & $\begin{array}{l}0.052^{\star \star *} \\
(0.014)\end{array}$ & $\begin{array}{c}0.100 \\
(0.909)\end{array}$ & 34 & $1950-1977$ \\
\hline Hay $^{2}$ & $\begin{array}{r}-0.070 \\
(0.046)\end{array}$ & $\begin{array}{c}0.550 \\
(0.410)\end{array}$ & 34 & $1976-1984$ \\
\hline Meat $^{2}$ & $\begin{array}{r}-0.020 \\
(0.028)\end{array}$ & $\begin{array}{c}0.070 \\
(0.241)\end{array}$ & 34 & $1976-1984$ \\
\hline Steers $^{2}$ & $\begin{array}{c}0.010 \\
(0.024)\end{array}$ & $\begin{array}{c}0.030 \\
(0.250)\end{array}$ & 34 & $1976-1984$ \\
\hline $\operatorname{Hog}^{2}$ & $\begin{array}{r}-0.050 \\
(0.046)\end{array}$ & $\begin{array}{c}0.270 \\
(0.386)\end{array}$ & 34 & $1976-1984$ \\
\hline Farmland and dividend ${ }^{2}$ & $\begin{array}{c}0.000 \\
(0.000)\end{array}$ & $\begin{array}{r}-0.040 \\
(0.148)\end{array}$ & 34 & $1976-1984$ \\
\hline 25th percentile of 41 agricultural assets ${ }^{3}$ & $\begin{array}{c}-0.020 \\
\text { NA }\end{array}$ & $\begin{array}{l}0.037 \\
N A\end{array}$ & NA & NA \\
\hline Median of 41 agricultural assets $^{3}$ & $\begin{array}{c}0.000 \\
\text { NA }\end{array}$ & $\begin{array}{l}0.100 \\
N A\end{array}$ & NA & NA \\
\hline 75th percentile of 41 agricultural assets ${ }^{3}$ & $\begin{array}{c}0.043 \\
\text { NA }\end{array}$ & $\begin{array}{l}0.215 \\
\text { NA }\end{array}$ & NA & NA \\
\hline
\end{tabular}

${ }^{1}$ Data from Barry (1980).

2Data from Arthur et al. (1988).

${ }^{3}$ Data from Dusak (1973), Barry (1980), and Arthur et al. (1988).

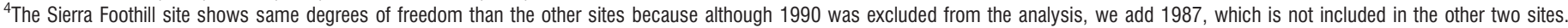

${ }^{5}$ Asterisks $\left({ }^{* *}\right)$ denote significance at the $1 \%$ level. NA indicates not applicable; SE, standard error.

variation in all cases (Table 3). Thus, higher risk and expected rate of return seems to be associated with higher fluctuations in forage production.

Since the risk levels $(\beta \mathrm{s})$ estimated in our regressions are both relatively small and not statistically significant, it is expected that the returns for the three simulated ranches will correspond to the expected return on the risk-free asset. This implies that investment in a cow-calf enterprise should produce at least the same return as the risk-free asset. The return of the risk-free asset in our analyzed period averaged $4.81 \%$ (ranging from $1.13 \%$ to $9.04 \%$ as minimum and maximum rates), which is very close to the expected net return obtained under the CAPM (Table 3).

\section{DISCUSSION}

Our results show that while cow-calf range-based production is risky, likely due to weather events and forage production variation, it carries relatively low systematic risk (each estimated $\beta$ is not significant in the models). This means that risk can be diversified by investing in other market assets, or through drought insurance that enables the insuring agent to

Table 3. Expected rate of return under the Capital Asset Pricing Model (CAPM) for each site, with their corresponding confidence intervals, and coefficient of variation of estimated rate of return and forage production.

\begin{tabular}{|c|c|c|c|c|c|}
\hline \multirow[b]{2}{*}{ Sites } & \multirow[b]{2}{*}{ Expected rate of return under CAPM } & \multicolumn{2}{|c|}{$95 \%$ confidence interval } & \multicolumn{2}{|c|}{ Coefficient of variation } \\
\hline & & Lower bound & Upper bound & Forage production & Estimated rate of return \\
\hline San Joaquin & $5.38 \%$ & $3.68 \%$ & $7.07 \%$ & 0.44 & 4.12 \\
\hline Hopland & $4.43 \%$ & $3.43 \%$ & $5.43 \%$ & 0.22 & 0.85 \\
\hline Sierra Foothills & $5.28 \%$ & $3.34 \%$ & $7.23 \%$ & 0.30 & 2.04 \\
\hline
\end{tabular}


diversify one of the main sources of the risk. This makes cowcalf production, as part of ranching operations, a relatively safe investment. However, average returns of $2 \%$ to $3 \%$ from livestock production on western rangelands as determined by a number of other studies that also do not consider land appreciation (see Workman 1986 and Torell et al. 2001 for more details), and of $3.29 \%$ from agriculture for the period 1964-1996 as reported in AAEA (2000; p. 2-41), are lower than the estimated theoretical cost of capital for cow-calf production $(\sim 5 \%)$ as determined by the CAPM results applied to three grassland sites in California. It must be noted, however, that the results from these studies are not perfectly comparable with our CAPM application, since they include more components as part of the ranch investment (the divisor in the rate of return), for example, land value.

Our CAPM results are consistent with prior studies of the market risk and return of agricultural assets (Dusak 1973; Barry 1980; Arthur et al. 1988). As presented in the AAEA (2000), using the CAPM and an inflation-adjusted CAPM there is little, if any, risk premium for holding agricultural assets. In the AAEA (2000), it is concluded that it is not clear that the risk rate of return for all of agriculture is any higher than for comparable nonagricultural assets.

According to these results, why ranchers engage in cow-calf operations may need an explanation apart from financial benefits. Given the costs of capital for other market assets, cowcalf producers incur an opportunity cost in their investments, and could be expecting additional returns of at least $1 \%$ to $3 \%$ per year, since they could invest in alternative risk-free assets that provide larger financial returns. As is well-documented in the literature, ranchers derive lifestyle or other nontangible benefits from their investments, may have alternative income streams such as hunting and land appreciation, and in fact many of them work off-ranch to support the benefits they derive (Smith and Martin 1972; Torell et al. 2001; Sulak and Huntsinger 2002; Rimbey et al. 2007; Campos et al. 2009; Huntsinger et al. 2010). Other investors, those coming from outside the ranching business, could feel that due to its low systematic risk cow-calf production has potential for diversifying risk in an investment portfolio. However, there seems to be some other motivation for this investment because risk-free assets can equally diversify risk in investment portfolios. Our results reinforce the concept of amenity motivations in cow-calf and ranching operations that have been approached in the literature using either hedonic pricing (Pope 1985; Torell et al. 2005) or contingent valuation (Campos et al. 2009) to find the returns that justify investments in range-based enterprises.

Land appreciation could be an explanatory factor for those owning the land but not for the cow-calf enterprise itself. By analyzing the potential risk associated with cow-calf production using the CAPM and real data variation in forage productivity and hay and cattle prices for a long time-series in three sites in California, we show that in the absence of land appreciation, ranching-related activities match the risk-free asset's theoretical returns in the market. Including land appreciation as part of a ranchland investment scenario could increase the investment rate of returns. Torell et al. (2001) note that the average $2 \%$ to $3 \%$ rate of return realized from cowcalf production on larger New Mexico ranches nearly doubles to about $5 \%$ once land appreciation is considered. The AAEA
(2000; p. 2-39) found that the rate of return from agriculture for the period $1964-1996$ is $5.40 \%$ when land appreciation is considered. However, the speculative nature of land appreciation returns could affect the $\beta$ (systematic risk) of a CAPM and we may find that there could be still a gap between the theoretical cost of capital and the historical returns reported for ranchland investment including land appreciation. Further research on the role of land appreciation returns in livestock production investment is needed.

While there is an insufficient number of sites in this study to draw definitive conclusions about variation in of forage productivity and its relationship with cost of capital, analysis of additional sites would be necessary. From the three sites that were analyzed, the observed positive correlation between the coefficient of variation for forage production and the expected return does suggest that year-to-year variability in forage production appears to be driving the expected rate of return on the cow-calf operations through our time-series analysis (Table 3).

This study uses specific rule-sets for simulating cow-calf enterprises that may not accurately reflect rancher behavior with respect to forage use. In fact, traditionally around the globe, rather than relying on a single area for forage production, ranchers and pastoralists have tended to maximize their flexibility and increase overall income stability by accessing diverse forage resources, taking advantage of the spatial mobility of livestock herding (Oba et al. 2000). For example, in our study area that might take the form of using grazing lands in areas with forage production patterns that complement the forage production on the base ranch such as high elevation Forest Service grazing allotments or grazing land in the adjacent intermountain west region. This will tend to buffer the year-to-year variability in forage costs for a rancher. Changes in herd sizes or use of irrigated pasture or cropland in response to forage variability will also impact the actual variability in forage costs and return on investment.

Climate change has been posited as likely to have major impacts on California forage production. Particularly in northern California's Central Valley and coast, mean annual precipitation is likely to decrease. Of particular concern is the projected 1.5- to 2.5-fold increase in drought frequency (Cayan et al. 2006). However, given the high level of site-specific uncertainty in climate change predictions, it is difficult to make predictions of exactly how climate change will affect the profitability and risk of ranching in California. Given the general pattern of low risk in agricultural assets, the risk and cost of capital of ranching in California will likely remain low with respect to climate change.

\section{MANAGEMENT IMPLICATIONS}

As variability in forage production is an important driver of the risk and cost of capital, finding ways to compensate for or "smooth" it is important. Cow-calf producers need low-cost ways to support their relatively inflexible herd numbers when forage is in short supply. The "grassbank" movement is a case in point (Gripne 2005), where land is set aside to be used only when needed for augmenting forage supplies. Use of agricultural byproducts as supplementary feed is another common 
adaptation strategy when ranches are in proximity to crop fields. When forage is abundant, finding ways to take advantage of it would also improve returns. Because of weather unpredictability this is difficult. It usually involves keeping some calves or grazing stockers, as annual California grasslands seldom make decent hay.

The estimations of the expected cost of capital and the apparent importance of amenity returns in ranch investment decisions may imply that the challenges to the livestock industry in California, and maybe across the western United States, are likely due to factors larger than the ability of an enterprise to meet its cost of capital. Finding ways to increase income streams, reduce costs and risks, and maximize amenity and production values are important to the long-term sustainability of ranching. Amenity values act as motivators to make ranchers willing to maintain their operations in rangeland working landscapes. Those interested in the sustainability of working rangeland landscapes need to understand both financial and amenity values and what might impact them. Further research into all the motivations and tradeoffs inherent in ranching as a socio-economic and ecological system is warranted when considering strategies for maintaining working landscapes.

\section{LITERATURE CITED}

[AaEa] American Agricultural Economics Association. 2000. Commodity costs and returns estimation handbook. A report of the AAEA Task Force on Commodity Costs and Returns. Ames, IA, USA: USDA. p 566.

Arthur, L. M., C. A. Carter, and F. Abizadeh. 1988. Arbitrage pricing, capital asset pricing, and agricultural assets. American Journal of Agricultural Economics 70:360-365.

BarRY, P. J. 1980. Capital asset pricing and farm real estate. American Journal of Agricultural Economics 62:549-553.

Bureau of Economic Analysis, National Economic Accounts. 2008. Implicit price deflators for Gross Domestic Product. Available at: http://www.bea.gov/national/nipaweb/ SelectTable.asp?Selected=N. Accessed February 2008.

California Chapter, American Society of Farm Managers and Rural Appraisers. 2007. Trends in agricultural land and lease values. Woodbridge, CA, USA. $88 \mathrm{p}$. Available at: http://www.calasfmra.com/trends.php. Accessed December 2007.

Campos, P., J. L. Oviedo, A. Caparrós, L. Hunstinger, and I. Coelho. 2009. Contingent valuation of woodland-owner private amenities in Spain, Portugal, and California. Rangeland Ecology \& Management 62:240-252.

Cayan, D., A. L. Luers, and G. Franco. 2006. Scenarios of climate change in California: an overview. California Climate Change Center. White Paper. Sacramento, CA, USA: California Energy Commission. Report CEC-500-2005-186-SF. 47 p.

DusAK, K. 1973. Futures trading and investor returns: an investigation of commodity market risk premiums. Journal of Political Economy 81:1387-1406.

Federal Reserve Board of Governors. 2007. Selected interest rates, historical data. Available at: http://www.federalreserve.gov/releases/h15/data.htm. Accessed December 2007.

Fire and Resource Assessment Program, California Department of Forestry and Fire Protection. 2003. The changing California: forest and range 2003 assessment. Available at: http:/frap.fire.ca.gov/assessment2003/. Accessed April 2008.

Forero, L. C., G. A. Nader, K. M. Klonsky, P. Livingston, and R. L. de Moura. 2004. Sample costs for beef cattle cow-calf production: 300 head. Davis, CA, USA: University of California Cooperative Extension. Available at: http://coststudies. ucdavis.edu/files/beefcowcalfsv2004.pdf. Accessed February 2008.

George, M., J. Bartolome, N. McDougald, M. Connor, C. Vaughn, and G. Markegard. 2001. Annual range forage production. Davis, CA, USA: University of California, Division of Agriculture and Natural Resources. Rangeland Management Series, Publication 8018. 9 p.

GRIPNE, S. L. 2005. Grassbanks: bartering for conservation. Rangelands 27(1):24-28.
Holechek, J. L., R. D. Pleper, and C. H. Herbel. 2004. Range management: principles and practices. Upper Saddle River, NJ, USA: Pearson Prentice Hall. 607 p.

Huntsinger, L., M. Johnson, M. StafFoRd, and J. Fried. 2010. Hardwood rangeland landowners in California from 1985 to 2004: production, ecosystem services, and permanence. Rangeland Ecology \& Management 63:324-334.

Liffmann, R. H., L. Huntsinger, And L. C. Forero. 2000. To ranch or not to ranch: home on the urban range? Journal of Range Management 53:362-370.

LINTNER, J. 1965. The valuation of risk assets and the selection of risky investments in stock portfolios and capital budgets. Review of Economics and Statistics 47:13-37.

MerToN, R. C. 1973. An intertemporal capital asset pricing model. Econometrica 41:867-887.

[NASS] National Agricultural Statistics Service. 2007. California publications. Available at: http://www.nass.usda.gov/Statistics_by_State/California/ Historical_Data/index.asp. Accessed January 2007.

ObA, G., N. C. STENSETH, ANd W. J. LuSIGI. 2000. New perspectives on sustainable grazing management in arid zones of Sub-Saharan Africa. BioScience 50(1):35-51.

POPE, C. A., III. 1985. Agricultural productive and consumptive use components of rural land values in Texas. American Journal of Agricultural Economics 67:81-86.

Pope, C. A., III. 1987. Agricultural productive and consumptive use components of rural land values in Texas: reply. American Journal of Agricultural Economics 69:179-181.

Rimbey, N. R., L. A. Torell, and J. A. Tanaka. 2007. Why grazing permits have economic value. Journal of Agricultural and Resource Economics 32:20-40.

ShaRpe, W. F. 1964. Capital asset prices: a theory of market equilibrium under conditions of risk. Journal of Finance 19:425-442.

SMITH, A. H., AND W. E. MARTIN. 1972. Socioeconomic behavior of cattle ranchers, with implications for rural community development in the west. American Journal of Agricultural Economics 54:217-225.

Standard and Poor's. 2007. Standard and Poor's 500 index. Available at: http://www. standardandpoors.com/indices/sp-500/en/us/?indexld—spusa-500-usduf--p-us----. Accessed December 2007.

StarRS, P. F. 1998. Let the cowboy ride. Baltimore, MD, USA: John Hopkins University Press. $356 \mathrm{p}$.

Sulak, A., AND L. Huntsinger. 2002. Sierra Nevada grazing in transition: the role of Forest Service grazing in the foothill ranches of California. Berkeley, CA, USA: Sierra Nevada Alliance, the California Cattlemen's Association, the California Rangeland Trust, and the Integrated Hardwood Range Management Program. 36 p. Available at: http://nature.berkeley.edu/huntsingerlab/Rangeland_Landowners_files/ 072 Huntsinger_Sierra_Lands.pdf.

ToReLL, L. A., AND S. A. BAllEY. 2000. Is the profit motive an important determinant of grazing land use and rancher motive? In: Selected Papers of Western Agricultural Economics Association Annual Meeting; 29 June-1 July 2000; Vancouver, BC, Canada. Laramie, WY, USA: Western Economics Association.

Torell, L. A., S. Murugan, and 0. A. Ramirez. 2010. Economics of flexible versus conservative stocking strategies to manage climate variability risk. Rangeland Ecology \& Management 63:415-425.

Torell, L. A., N. R. Rimbey, O. A. Ramirez, and D. W. McCollum. 2005. Income earning potential versus consumptive amenities in determining ranchland values. Journal of Agricultural and Resource Economics 30:537-560.

Torell, L. A., N. R. Rimbey, J. A. Tanaka, and S. A. Bailey. 2001. The lack of profit motive for ranching: implications for policy analysis. In: L. A. Torell, E. T. Bartlett, and R. Larrañaga [EDS.]. Proceedings of the Annual Meeting of the Society for Range Management; 17-23 February 2001; Kailua-Kona, HI, USA. Wheat Ridge, CO, USA: Society for Range Management. p. 47-58.

[USDA] US Department of Agriculture. 2000. Summary report: 1997 national resources inventory (revised December 2000). Washington, DC, USA: USDANRCS; and Ames, IA, USA: Statistical Laboratory, lowa State University. 89 p.

USDA. 2003. Natural resources inventory. Natural Resources Conservation Services. Available at: http://www.nrcs.usda.gov/technical/NRI/. Accessed April 2008.

USDA. 2011. Commodity costs and returns: data. Economic Research Service. Available at: http://www.ers.usda.gov/Data/CostsAndReturns/testpick.htm. Accessed December 2011.

VETTER, S. 2005. Rangelands at equilibrium and nonequilibrium: recent developments in the debate. Journal of Arid Environments 62:321-341.

Workman, J. P. 1986. Range economics. New York, NY, USA: MacMillan Publishing. $217 p$ 
Appendix 1. Example of financial Statements for cow-calf production for year 2007 in San Joaquin, Hopland, and Sierra Foothill sites. These financial statements were simulated for each year in the period 1988-2007 for the San Joaquin and Hopland sites and for the year 1987 and each year in the period 1989-2007 for the Sierra Foothill site. Benefits are estimated as revenues minus costs, and the Return on Investment rate is estimated as Benefits divided by Investment multiplied by 100 .

\begin{tabular}{|c|c|c|c|c|c|c|c|c|c|c|c|c|c|c|c|}
\hline & \multicolumn{5}{|c|}{ San Joaquin site ${ }^{1}$} & \multicolumn{5}{|c|}{ Hopland site } & \multicolumn{5}{|c|}{ Sierra Foothill site } \\
\hline & $\begin{array}{l}\text { Weight } \\
(\mathrm{kg})\end{array}$ & Unit & $n^{\circ}$ & $\begin{array}{c}\text { Price } \\
\left(\$ \cdot \mathrm{kg}^{-1}\right)\end{array}$ & $\begin{array}{l}\text { Total value } \\
(\$)\end{array}$ & $\begin{array}{l}\text { Weight } \\
(\mathrm{kg})\end{array}$ & Unit & $\mathrm{n}^{\circ}$ & $\begin{array}{c}\text { Price } \\
\left(\$ \cdot \mathrm{kg}^{-1}\right)\end{array}$ & $\begin{array}{l}\text { Total value } \\
(\$)\end{array}$ & $\begin{array}{c}\text { Weight } \\
(\mathrm{kg})\end{array}$ & Unit & $n^{\circ}$ & $\begin{array}{c}\text { Price } \\
\left(\$ \cdot \mathrm{kg}^{-1}\right)\end{array}$ & $\begin{array}{c}\text { Total value } \\
(\$)\end{array}$ \\
\hline \multicolumn{16}{|l|}{ Revenues } \\
\hline Steer calves & 273 & head & 118 & 2.461 & 79296 & 273 & head & 118 & 2.461 & 79296 & 273 & head & 118 & 2.461 & 79296 \\
\hline Heifers calves & 260 & head & 87 & 2.477 & 56028 & 260 & head & 87 & 2.477 & 56028 & 260 & head & 87 & 2.477 & 56028 \\
\hline Yearling heifers & 341 & head & 8 & 2.120 & 5784 & 341 & head & 8 & 2.120 & 5784 & 341 & head & 8 & 2.120 & 5784 \\
\hline Cull cows & 523 & head & 24 & 0.994 & 12475 & 523 & head & 24 & 0.994 & 12475 & 523 & head & 24 & 0.994 & 12475 \\
\hline Cull bulls & 795 & head & 2 & 0.995 & 1582 & 795 & head & 2 & 0.995 & 1582 & 795 & head & 2 & 0.995 & 1582 \\
\hline Total revenues & & & & & 155165 & & & & & 155165 & & & & & 155165 \\
\hline \multicolumn{16}{|l|}{ Costs } \\
\hline Forage lease & & ha & 1426 & 27.19 & 38778 & & ha & 1160 & 36.21 & 42000 & & ha & 982 & 44.53 & 43725 \\
\hline Hay & & ton & 749 & 153.00 & 114561 & & ton & 0 & 153.00 & 0 & & ton & 0 & 153.00 & 0 \\
\hline Gas & & liter & 15142 & 0.695 & 10524 & & liter & 15142 & 0.695 & 10524 & & liter & 15142 & 0.695 & 10524 \\
\hline Bull purchase & 795 & head & 3 & 1054.67 & 3164 & 795 & head & 3 & 1054.67 & 3164 & 795 & head & 3 & 1054.67 & 3164 \\
\hline Other costs & & & & & 70000 & & & & & 70000 & & & & & 70000 \\
\hline Total cost & & & & & 237027 & & & & & 125688 & & & & & 127413 \\
\hline Benefits & & & & & -81862 & & & & & 29477 & & & & & 27753 \\
\hline Investment & & & & & 500000 & & & & & 500000 & & & & & 500000 \\
\hline Return on investment rate & & & & & $-16.37 \%$ & & & & & $5.90 \%$ & & & & & $5.55 \%$ \\
\hline
\end{tabular}

${ }^{1}$ Units in this table and throughout the text are converted to metric units, although the calculations were originally made based on pounds, gallons, acres and $\$ \cdot \mathrm{cwt}^{-1}$ units.

Appendix 2. Sensitivity analysis of the results of $\alpha$ and $\beta$ for the Capital Asset Pricing Model for three simulated cow-calf production sites in California.

\begin{tabular}{|c|c|c|c|c|c|c|}
\hline \multirow[b]{3}{*}{ Sites $^{1,2}$} & \multicolumn{6}{|c|}{ Sensitivity analysis scenarios } \\
\hline & \multicolumn{2}{|c|}{$10 \%$ decrease in other costs and investment } & \multicolumn{2}{|c|}{$10 \%$ increase in other costs and investment } & \multicolumn{2}{|c|}{$20 \%$ increase in other costs and investment } \\
\hline & $\alpha(\mathrm{SE})$ & $\beta$ (SE) & $\alpha(\mathrm{SE})$ & $\beta$ (SE) & $\alpha(\mathrm{SE})$ & $\beta$ (SE) \\
\hline \multirow[t]{2}{*}{ Cow-calf, San Joaquin site } & -0.016 & 0.087 & $-0.047^{\star \star}$ & 0.071 & $-0.059^{\star \star \star}$ & 0.065 \\
\hline & $(0.024)$ & $(0.131)$ & $(0.020)$ & $(0.110)$ & $(0.019)$ & $(0.102)$ \\
\hline \multirow[t]{2}{*}{ Cow-calf, Hopland site } & $0.041^{\star \star \star}$ & -0.057 & 0.000 & -0.047 & -0.015 & -0.043 \\
\hline & $(0.014)$ & $(0.076)$ & $(0.012)$ & $(0.063)$ & $(0.011)$ & $(0.059)$ \\
\hline \multirow[t]{2}{*}{ Cow-calf, Sierra Foothill site } & -0.007 & 0.022 & $-0.038^{\star \star}$ & 0.052 & $-0.050^{\star \star *}$ & 0.046 \\
\hline & $(0.068)$ & $(0.109)$ & $(0.018)$ & $(0.091)$ & $(0.017)$ & $(0.084)$ \\
\hline
\end{tabular}

${ }^{1}$ Number of observations is 20 for each site, as it can be seen in Table 1 in the main text.

${ }^{2}$ Asterisks denote significance at the $1 \%$ and $5 \%$ level, respectively. SE indicates standard error. 